\title{
The effects of ACTH on steroid metabolomic profiles in human adrenal cells
}

\author{
Yewei Xing, Michael A Edwards, Clarence Ahlem', Mike Kennedy ${ }^{1}$, Anthony Cohen, \\ Celso E Gomez-Sanchez ${ }^{2}$ and William E Rainey \\ Department of Physiology and Surgery, Georgia Health University, 1120 15th Street, Augusta, Georgia 30912, USA \\ ${ }^{1}$ Hollis-Eden Pharmaceuticals, Inc., San Diego, California 921222, USA \\ ${ }^{2}$ University of Mississippi Medical Center, Jackson, Mississippi 39126, USA \\ (Correspondence should be addressed to W E Rainey; Email: wrainey@mcg.edu)
}

\begin{abstract}
The adrenal glands are the primary source of mineralocorticoids, glucocorticoids, and the so-called adrenal androgens. Under physiological conditions, cortisol and adrenal androgen synthesis are controlled primarily by ACTH. Although it is well established that ACTH can stimulate steroidogenesis in the human adrenal gland, the effect of ACTH on overall production of different classes of steroid hormones has not been defined. In this study, we examined the effect of ACTH on the production of 23 steroid hormones in adult adrenal primary cultures and 20 steroids in the adrenal cell line, H295R. Liquid chromatography/tandem mass spectrometry analysis revealed that, in primary adrenal cell cultures, cortisol and corticosterone were the two most abundant steroid hormones produced with or without

ACTH treatment $(48 \mathrm{~h})$. Cortisol production responded the most to ACTH treatment, with a 64-fold increase. Interestingly, the production of two androgens, androstenedione and $11 \beta$-hydroxyandrostenedione (11OHA), that were also produced in large amounts under basal conditions significantly increased after ACTH incubation. In H295R cells, 11-deoxycortisol and androstenedione were the major products under basal conditions. Treatment with forskolin increased the percentage of $11 \beta$-hydroxylated products, including cortisol and 11OHA. This study illustrates that adrenal cells respond to $\mathrm{ACTH}$ through the secretion of a variety of steroid hormones, thus supporting the role of adrenal cells as a source of both corticosteroids and androgens. Journal of Endocrinology (2011) 209, 327-335
\end{abstract}

\section{Introduction}

The human adult adrenal cortex can be divided into three functionally distinct zones, namely the zona glomerulosa $(\mathrm{ZG})$, zona fasciculata $(\mathrm{ZF})$, and zona reticularis (ZR). Each zone exhibits independent regulation and function, as illustrated by the selective production of glucocorticoids in the ZF, mineralocorticoids in the ZG, and adrenal androgens in the ZR. Adrenal androgens include mainly DHEA, DHEA-S, and androstenedione, which exhibit only weak sex hormone activity but can serve as precursors for estrogens and active androgens such as testosterone (Branchaud et al. 1983, Haning et al. 1985, Chen et al. 1996, Labrie et al. 1998, Burger 2002). In addition to the end products of steroid hormone synthesis, adrenal steroid intermediates can also be detected in blood and used as biomarkers for adrenal disease.

ACTH, by binding to its specific G-protein coupled receptor $\mathrm{MC} 2 \mathrm{R}$, has been shown to induce adrenal cortex proliferation and steroidogenesis (Ney et al. 1969, Sharma 1973, Mahaffee et al. 1974, Hornsby \& Gill 1977, Di Blasio et al. 1990). ACTH can stimulate aldosterone, cortisol, and DHEA production in the adrenal cells (Hornsby et al. 1973,
Hung \& LeMaire 1988, Arvat et al. 2000, Sirianni et al. 2005). However, it is not clear if these steroids represent the most abundant steroids secreted in response to ACTH. O'Hare et al. (1976), using HPLC, demonstrated the production of cortisol, corticosterone, 11-deoxycortisol, 11-deoxycorticosterone, androstenedione, 11 $\beta$-hydroxyandrostenedione (11OHA), and $16 \alpha$-hydroxyprogesterone in primary cultures of human adrenocortical cells (Morgan \& O'Hare 1979). However, the amounts of individual steroids were not quantified and effects of ACTH were examined only for a few steroids.

Given the critical role of ACTH in adrenal development, steroidogenesis, and disease, it is appropriate to further determine the detailed effects of ACTH on steroid biosynthesis. In this study, we used liquid chromatography/ tandem mass spectrometry analysis (LC-MS/MS) to measure the production of 23 steroid hormones in primary cultures of adrenocortical cells under basal conditions and in response to ACTH treatment. The study has characterized the metabolomic pattern of adrenocortical cells and defined a family of ACTH-responsive steroids, thus expanding our knowledge of ACTH action in the human adrenal. 


\section{Materials and Methods}

\section{Tissue collection}

Human adult adrenal glands were obtained from cadaveric kidney donors that were transplanted at the Georgia Health University (Augusta, GA, USA). Informed consent was obtained from the family of the donor by LifeLink of Georgia. The use of these tissues was approved by the Institutional Review Board of Georgia Health University.

\section{Cell culture and treatment}

Adult adrenocortical (AA) cells were isolated with collagenase-dispase digestion, as described previously (Bassett et al. 2004). Briefly, adult adrenals were minced and dissociated into a single cell suspension by repeated exposure of the tissue fragments to DMEM/F12 medium (Invitrogen) containing $1 \mathrm{mg} / \mathrm{ml}$ collagenase dispase and $0 \cdot 25 \mathrm{mg} / \mathrm{ml}$ DNase-1 (F. Hoffmann-La Roche Ltd, Basel, Switzerland). Digestion and mechanical dispersion were carried out four times for $1 \mathrm{~h}$ each, at $37^{\circ} \mathrm{C}$. Cells were collected between each digestion and combined, then plated at a density of 300000 cells/well in 24-well Falcon cell culture plates.

Steroid production was measured after the AA cells were grown in a complete growth medium (DMEM/F12 medium with 10\% Cosmic calf serum (HyClone, Logan, UT, USA) and antibiotics) for 5 days. Prior to ACTH stimulation, the cells were cultured in experimental medium $(0 \cdot 1 \%$ Cosmic calf serum and antibiotics) overnight and then treated with vehicle or $10 \mathrm{nM}$ ACTH (Organon, Bedford, OH, USA) for $48 \mathrm{~h}$. The cells were lysed for protein assay and media were collected for steroid assays, as described below.

H295R cells were cultured using the same complete growth medium as for AA cells, while H295R subclones, HAC13 and HAC15, were grown in DME/F12 medium supplemented with $10 \%$ cosmic calf serum, 1\% insulin/ transferrin/selenium premix (ITS, BD Biosciences, Franklin Lakes, NJ, USA), and antibiotics. All three lines were plated at a density of 400000 cells/well in a 12-well dish and treated with vehicle or forskolin $(10 \mu \mathrm{M}$, Sigma-Aldrich) following the same protocol.

\section{Protein extraction and protein assay}

Cells were lyzed in $100 \mu \mathrm{l}$ Mammalian Protein Extraction Reagent (Pierce Chemical Co., Rockford, IL, USA), and the protein content was estimated by the bicinchoninic acid (BCA) protein assay using the micro BCA protocol (Thermo Scientific, Rockford, IL, USA).

\section{Liquid chromatography/tandem mass spectrometry}

Deuterium-labeled 4-androstenedione, corticosterone, estradiol $\left(\mathrm{E}_{2}\right)$, pregnenolone, and testosterone were purchased from CDN Isotopes (Pointe-Claire, Canada). All other steroids were purchased from Steraloids (Newport, RI, USA). HPLC solvents and water were of HPLC analytical grade and filtered $(0 \cdot 2 \mu \mathrm{m})$ before use. All other reagents were purchased from Sigma and were of analytical grade or better.

Calibration curves were prepared by serial dilution of analytical standards in water. Quality control (QC) samples were prepared for each steroid analyzed. QC samples were prepared in experimental medium $(0 \cdot 1 \%$ Cosmic calf serum and $1 \%$ antibiotics) spiked with analyte at concentrations near the lower, mid, and upper region of the range of quantification. Calibration curves and QC samples were analyzed in parallel with experimental samples. Steroid concentrations were calculated by Masslynx Software (Waters, Beverly, MA, USA), with the assumed concentrations for the standards calculated from the calibration curve regression parameters in comparison to theoretical values. The accuracy of QC samples was determined after first subtracting the endogenous concentration determined in experimental medium from the total concentration found in the QC sample.

Steroids of interest were assigned to one of three categories for quantification by LC-MS/MS based on the need for precolumn derivatization to achieve an appropriate lower-limit quantification and/or chromatographic resolution: 1) no precolumn derivatization needed, 2) keto-steroids amenable to condensation with hydroxylamine, and 3) $\mathrm{E}_{2}$ and estrone. Each method used one or more deuterium-labeled internal standards. Calibration curves and QC samples used for each method were prepared with the corresponding pre-column derivatization method (See supplemental Tables 1 and 2, see section on supplementary data given at the end of this article for details regarding internal standards, retention times, quantified mass transitions, assay performance parameters and statistics, and detection limits for steroid measurement).

Method 1 LC-MS/MS without pre-column derivatization (5-androstenediol, androstenedione, corticosterone, cortisol, DHEA, 11-deoxycorticosterone, 11-deoxycortisol, 17 $\alpha$ hydroxyprogesterone, 20 $\alpha$-hydroxyprogesterone, and testosterone).

Samples $(100 \mu \mathrm{l})$ were extracted with $4 \mathrm{ml}$ methyl-tert-butyl ether (MTBE). The organic phase was evaporated to dryness and reconstituted in $200 \mu \mathrm{l}$ of water/acetonitrile $(75: 25, \mathrm{v}: \mathrm{v})$. The reconstituted samples $(20 \mu \mathrm{l})$ were applied to an Xterra C18 column $(2 \cdot 1 \times 250 \mathrm{~mm}, 5 \mu \mathrm{m}$, Waters $)$, and eluted with a mobile phase gradient of $30-85 \%$ acetonitrile in water, with $0 \cdot 1 \%$ formic acid. The column temperature was maintained at $40{ }^{\circ} \mathrm{C}$. The column eluent was subjected to positive-mode electrospray ionization $\left(\mathrm{ES}^{+}\right)$, and the analytes were detected with a tandem quadrupole mass spectrometer (Waters).

Method 2 LC-MS/MS analysis of oxime derivatives of keto-steroids (aldosterone, dihydrotestosterone, 11OHA, $7 \alpha$-DHEA, 16 $\alpha$-DHEA, 17 $\alpha$-hydroxypregnenolone, pregnenolone, and progesterone). 
Samples $(100 \mu \mathrm{l})$ were extracted with $4 \mathrm{ml}$ MTBE, and the organic phase was evaporated to dryness. The residue was dissolved in $1 \mathrm{M}$ aqueous hydroxylamine hydrochloride, and incubated for $1 \mathrm{~h}$ at $60^{\circ} \mathrm{C}$. The reaction mixtures were extracted with $2.5 \mathrm{ml} \mathrm{MTBE}$, dried, and reconstituted in $200 \mu \mathrm{l}$ of water/acetonitrile $(75: 25, \mathrm{v}: \mathrm{v})$, and analyzed as above using a mobile phase gradient of $25-60 \%$ acetonitrile in water, with $0 \cdot 1 \%$ formic acid.

Method 3 LC-MS/MS analysis of dansylated $\mathrm{E}_{2}$ and estrone.

Samples $(100 \mu \mathrm{l})$ were extracted and dried as above, dissolved in $0.2 \mathrm{ml}$ of $1 \mathrm{mg} / \mathrm{ml}$ dansyl chloride in $1 \mathrm{M}$ aqueous sodium bicarbonate, and incubated for $1 \mathrm{~h}$ at $60^{\circ} \mathrm{C}$. The reaction mixtures $(20 \mu \mathrm{l})$ were analyzed by LC-MS/MS as above using an Xbridge Phenyl column $(2 \cdot 1 \times 150 \mathrm{~mm}$, $5 \mu \mathrm{m}$, Waters) with a mobile phase gradient of 35-90\% acetonitrile in water, with $0 \cdot 1 \%$ formic acid.

\section{Steroid immunoassay}

Steroid concentrations in the medium were determined using enzyme immunoassay (EIA) for cortisol (Alpco, Salem, NH, USA) and corticosterone (DRG International, Inc., Mountainside, NJ, USA), following the manufacturer recommendation, except that standard curves were prepared in the experimental cell culture medium. Immunoassay for $11 \mathrm{OHA}$ was developed in our laboratory. Briefly, plates were coated with rabbit IgG $1 \mu \mathrm{g} / 100 \mu \mathrm{l}$ (LAMPIRE Biological Laboratories, Inc., Pipersville, PA, USA) overnight in a $1 \mathrm{M} \mathrm{NaCl}$, $10 \mathrm{mM}$ phosphate buffer, $\mathrm{pH} \mathrm{7 \cdot 4}$. Plates were then washed four times in PBS buffer and incubated with $100 \mu$ goat antirabbit IgG antisera (LAMPIRE Biological Laboratories) 1/500 in PBS for $1 \mathrm{~h}$. Before each assay, coated plates were washed four times in PBS and $50 \mu$ of standards and sample were added to each well. 11OHA antibody $(50 \mu \mathrm{l})$ was added to each well at a 1:10 000 dilution (in PBS buffer) and mixed on shaker for $5 \mathrm{~min}$. Biotin-labeled 110HA $(50 \mu \mathrm{l}$, 1:12 000000 dilution in PBS) was added to each well and mixed for another $5 \mathrm{~min}$. The plate was then placed at $4{ }^{\circ} \mathrm{C}$ and allowed to incubate for $18 \mathrm{~h}$. Plates were washed four times in PBS and $150 \mu$ l of avidin-HRP (Vector Laboratories, Burlingame, CA, USA) was added at a 1:2500 dilution to each well. Plates were shaken for $30 \mathrm{~min}$, followed by fourtime washes in PBS and developed for $15 \mathrm{~min}$ with $100 \mu \mathrm{l} /$ well $\left(0 \cdot 2 \mathrm{~g} / 1\right.$ in $\left.0 \cdot 01 \% \mathrm{H}_{2} \mathrm{O}_{2}\right)$ tetramethylbenzidine substrate (Thermo Scientific, Waltham, MA, USA). The reaction was stopped with $50 \mu \mathrm{l} /$ well $1 \mathrm{~N}$ sulfuric acid. Absorbance was measured at $450 \mathrm{~nm}$. Results were normalized to protein/tissue culture well and shown as fold changes compared with basal.

\section{Statistical analysis}

Individual experiments were repeated three times, using cells isolated from adrenal glands obtained from different donors. Results are given as means \pm s.E.M. Statistics were calculated using the two-tail paired Student's t-test (GraphPad Prism 3.0, GraphPad Software, Inc., San Diego, CA, USA). A value of $P<0 \cdot 05$ was considered statistically significant.

\section{Results}

The major steroidogenic pathways for adrenal and gonadal tissues are shown in Fig. 1. Twenty-three steroid hormones were quantified in the medium from AA cells with and



Figure 1 Steroid biosynthesis pathways. Summary of the steroidogenic pathways leading to synthesis of glucocorticoids, mineralocorticoids, androgens, and estrogens. 
without ACTH stimulation, using LC-MS/MS and RIA (Table 1). Under basal conditions, the three most abundant steroids produced by AA cells were cortisol (31\%), cortisone $(15 \%)$, and corticosterone (13\%). Interestingly, two androgens, androstenedione and 11OHA, were also produced by adrenal cells in relatively high amounts (4 and 9\% respectively).

Following treatment with ACTH for $48 \mathrm{~h}$, the production of aldosterone, cortisol, DHEA, and all detectable intermediate products of each steroidogenic pathway increased by $\sim 4-60$ fold. (Table 1). The most highly stimulated steroids were cortisol (63-fold), corticosterone (37-fold), and 11-deoxycortisol (23-fold). Production of the adrenal androgens, androstenedione (26-fold), DHEA (18-fold), and 11OHA (17-fold), was also stimulated by ACTH treatment. The results of individual experiments using AA cells isolated from three different donors are shown for cortisol, corticosterone, 11-deoxycortisol, and 11OHA (Fig. 2). EIA was used to confirm the effects of ACTH on the steroid production in AA cells (Fig. 3). The relative increases of cortisol, corticosterone, and 11OHA were $\sim 2$-fold lower with EIA compared with LC-MS/MS, but both analytical methods indicated significant increases in the production of all the three steroids after ACTH treatment.
Comparison of the ratio of individual steroids produced by AA cell primary culture shows that cortisol represents $30 \%$ of total steroids made under basal conditions and 61\% after ACTH treatment (Fig. 4A). Increased cortisol production following treatment confirmed that ACTH is a potent stimulator of glucocorticoid synthesis that greatly increases the capacity of the adrenal to produce cortisol under the control of the hypothalamic-pituitary-adrenal (HPA) axis. The global decrease in the production of other steroidogenic intermediates after ACTH treatment was consistent with the known effects of ACTH on steroidogenesis. The pie chart summarizing the ratio of individual steroids to total steroids before and after ACTH treatment is shown in Fig. 4B.

Similar experiments were performed in three different H295R cell models, followed by the same analysis of their steroid metabolomic profile (Fig. 5). The only experimental change was the use of forskolin instead of ACTH as an agonist for steroidogenesis, because the HAC15, HAC13, and H295R only have minor response to ACTH. As opposed to AA primary cultures, H295R cell models mainly produced 11-deoxycortisol under both basal and stimulated conditions (42 vs 30\%), while androstenedione was also produced in large amount $(29 \%$ at basal versus $21 \%$ after forskolin treatment). In addition, cortisol was a significant product of

Table 1 Steroids produced under basal and ACTH treatments. AA cells were incubated with/without ACTH (10 nM) for $48 \mathrm{~h}$. Steroids were grouped according to carbon number and property. Concentrations of steroids were measured using liquid chromatography/tandem mass spectrometry analysis method and normalized to protein amount. Data represent results from three independent experiments and shown as means \pm S.E.M.

\begin{tabular}{|c|c|c|c|c|}
\hline Steroid & $\begin{array}{l}\text { Pre-ACTH } \\
\text { (pmol/mg protein) }\end{array}$ & $\begin{array}{l}\text { Post ACTH } \\
\text { (pmol/mg protein) }\end{array}$ & Fold change & $P$ value \\
\hline \multicolumn{5}{|l|}{ 21-Carbon steroids } \\
\hline Pregnenolone & $9 \cdot 6 \pm 4 \cdot 1$ & $136 \cdot 6 \pm 74 \cdot 6$ & $13 \cdot 4 \pm 3 \cdot 6$ & $0 \cdot 07$ \\
\hline $17 \alpha$-Hydroxypregnenolone & $16 \cdot 9 \pm 10 \cdot 0$ & $392 \cdot 0 \pm 211 \cdot 1$ & $32 \cdot 2 \pm 14 \cdot 0$ & $0 \cdot 15$ \\
\hline Progesterone & $12 \cdot 1 \pm 4 \cdot 0$ & $73 \cdot 0 \pm 31 \cdot 3$ & $5 \cdot 3 \pm 1 \cdot 4$ & $0 \cdot 09$ \\
\hline $17 \alpha$-Hydroxyprogesterone & $88 \cdot 7 \pm 27 \cdot 3$ & $1167 \cdot 4 \pm 512 \cdot 0$ & $15 \cdot 6 \pm 6 \cdot 2$ & $0 \cdot 14$ \\
\hline $20 \alpha$-Hydroxyprogesterone & ND & ND & - & - \\
\hline Deoxycorticosterone & $60 \cdot 5 \pm 30 \cdot 9$ & $613 \cdot 1 \pm 272 \cdot 3$ & $12 \cdot 8 \pm 2 \cdot 7^{*}$ & $0 \cdot 05$ \\
\hline Corticosterone & $243 \cdot 8 \pm 85 \cdot 8$ & $9183 \cdot 9 \pm 3392 \cdot 5$ & $37 \cdot 0 \pm 1 \cdot 3^{*}$ & $0 \cdot 001$ \\
\hline Aldosterone $^{\mathrm{a}}$ & $21 \cdot 8 \pm 1 \cdot 4$ & $201 \cdot 3 \pm 18 \cdot 2$ & $9 \cdot 3 \pm 1 \cdot 1^{*}$ & $0 \cdot 02$ \\
\hline 11-Deoxycortisol & $147 \cdot 2 \pm 41 \cdot 0$ & $3406 \cdot 6 \pm 968 \cdot 2$ & $23 \cdot 1 \pm 0 \cdot 7^{*}$ & $0 \cdot 001$ \\
\hline Cortisol & $514 \cdot 6 \pm 94 \cdot 4$ & $31464 \cdot 4 \pm 5609 \cdot 2$ & $63 \cdot 4 \pm 13 \cdot 3 *$ & $0 \cdot 04$ \\
\hline Cortisone & $259 \cdot 3 \pm 81 \cdot 5$ & $988 \cdot 0 \pm 340 \cdot 2$ & $3 \cdot 7 \pm 0 \cdot 5^{*}$ & $0 \cdot 04$ \\
\hline 11-Dehydrocorticosterone & $111 \cdot 5 \pm 81 \cdot 5$ & $535 \cdot 7 \pm 239 \cdot 7$ & $4 \cdot 9 \pm 0 \cdot 7^{*}$ & $0 \cdot 03$ \\
\hline \multicolumn{5}{|l|}{ 19-Carbon steroids } \\
\hline DHEA & $8 \cdot 5 \pm 2 \cdot 7$ & $188 \cdot 3 \pm 142 \cdot 3$ & $17 \cdot 6 \pm 9 \cdot 2$ & $0 \cdot 21$ \\
\hline DHEA-S & $\overline{N D}$ & $582 \cdot 8 \pm 83 \cdot 4$ & - & - \\
\hline $7 \alpha$-DHEA & ND & ND & - & _- \\
\hline $16 \alpha$-DHEA & ND & ND & - & - \\
\hline Androstenediol & ND & ND & - & - \\
\hline Androstenedione & $84 \cdot 1 \pm 44 \cdot 6$ & $2059 \cdot 6 \pm 999 \cdot 1$ & $25 \cdot 7 \pm 1 \cdot 2^{*}$ & $0 \cdot 002$ \\
\hline $11 \mathrm{OHA}$ & $174 \cdot 7 \pm 40 \cdot 4$ & $2844 \cdot 0 \pm 545 \cdot 5$ & $16 \cdot 6 \pm 1 \cdot 1^{*}$ & $0 \cdot 005$ \\
\hline Testosterone & ND & $11 \cdot 43 \pm 6.08$ & - & - \\
\hline Dihydrotestosterone & ND & ND & - & - \\
\hline \multicolumn{5}{|l|}{ 18-Carbon steroids } \\
\hline Estrone & ND & $23 \cdot 6 \pm 12 \cdot 3$ & - & - \\
\hline Estradiol & ND & ND & - & - \\
\hline
\end{tabular}

$P$ values were calculated using the paired $t$-test with $95 \%$ confidence intervals. $* P<0 \cdot 05$; ND, not detectable.

${ }^{a}$ Aldosterone is shown as RIA data due to the low concentration present in experiment medium. As a conjugated steroid, DHEA-S was also measured by immunoassay. The detection limit for DHEA-S is 140 . 

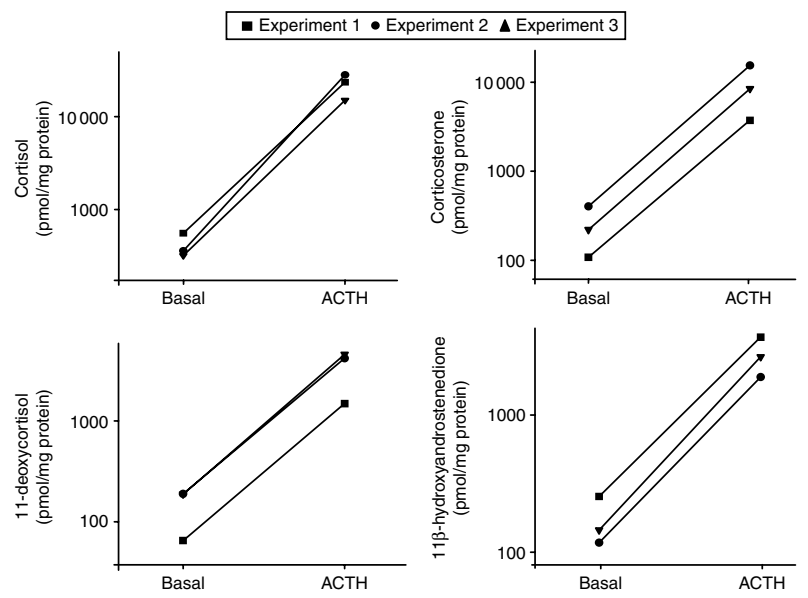

Figure 2 Major steroids produced by AA cells with/without ACTH treatment. Primary human adrenal culture cells were isolated as described in Materials and Methods, and plated at a density of 300000 cells/well in 24-well dishes. Cells were treated with/ without ACTH (10 nM) for $48 \mathrm{~h}$ before harvest. The concentration of steroids in the medium was measured by LC-MS/MS and normalized to the amount of protein. The amount of four major steroids produced by AA cells, cortisol, corticosterone, 11-deoxycortisol, and 11OHA, are shown in the graphs, with each line representing an individual, independent experiment.

the H295R cells, representing $10 \%$ of the steroids measured under basal conditions. The reason for a greater output of 11-deoxycortisol than cortisol may relate to the low basal expression of 11ß-hydroxylase (CYP11B1) in H295R cells (data not shown). Treatment with forskolin increased the relative output of cortisol production to $26 \%$, which corresponded to increases in CYP11B1 expression (data not shown). The stimulating effects of forskolin on CYP11B1 were also supported by increases in other 11-hydroxylated steroids (11-fold for cortisol, 13-fold for corticosterone, and 5 -fold for 11OHA). Although representing only a small portion of the total steroid made by the H295R (Fig. 5), the two steroids with the greatest forskolin-stimulated fold increase were estrone (20-fold) and $\mathrm{E}_{2}$ (19-fold), confirming that forskolin activates aromatase expression and activity (Watanabe \& Nakajin 2004). Cortisone and 11-dehydrocorticosterone concentrations were not quantified for the H295R experiments.

\section{Discussion}

Adrenal steroidogenesis has been extensively studied over the past 50 years (Grant 1962, Mason \& Fraser 1975, Lebrethon et al. 1994a,b, Fottner et al. 1998); however, the breadth of analytes considered in previous studies was limited by the available analytical technology. Previously reported in vitro studies have used isolated human adrenal cells as short-term dispersed cultures as well as long-term monolayer cultures. Short-term experiments using suspension cultures of human adrenocortical cells found a dose-dependent stimulatory effect of ACTH on cortisol, corticosterone, androstenedione, and DHEA/DHEA-S synthesis (Keymolen et al. 1976). Longterm monolayer cultures have been useful to study steroid production; however, the steroid synthesis profile in those cells were not well characterized. Fottner et al. (1998) tested the stimulating effects of ACTH only on cortisol and DHEA-S, while Guillon et al. (1995) tested four steroids (aldosterone, corticosterone, cortisol, and 17-hydroxyprogesterone), but only after short-term ACTH treatment (2 h; Guillon et al. 1995). The two different studies by Lebrethon et al. $(1994 a, b)$ used $2 \mathrm{~h}$ treatment times for ACTH and only changes in cortisol, aldosterone, or DHEA were measured in individual studies. In the current study, we used primary cultures of human adrenocortical cells as a model to describe the broad effects of ACTH on steroidogenesis. Our LC-MS/MS quantification of 23 steroids in response to ACTH stimulation is a significant extension of previous reports with regard to the model, the effects of ACTH, and the analytical methodology, and provides a comprehensive overview of chronic ACTH effects on the steroid profile.

Our LC/MS-MS data coincide with previous reports that cortisol is the major steroid stimulated by ACTH (O'Hare \& Neville 1974, Israeli et al. 1975, Kolanowski \& Crabbe 1976). All the intermediates of the cortisol-producing pathway, including $17 \alpha$-hydroxypregnenolone, $17 \alpha$-hydorxyprogesterone, and 11-deoxycortisol, were detectable under basal conditions and the presence of high levels of 11-deoxycortisol suggests that CYP11B1 can be a late rate-limiting step in


Figure 3 Time-dependent stimulation of three major steroids produced in AA cells by ACTH treatment. Primary human adrenal culture cells were isolated as described in Materials and Methods, and plated at a density of 300000 cells/well in 24-well dishes. Cells were treated with/without ACTH $(10 \mathrm{nM})$ for indicated times. The concentration of steroids (cortisol, corticosterone, and 11OHA) in the medium was measured by immunoassay and expressed as fold changes over basal level. Results represent means \pm s.E.M. of data from at least three experiments using cells isolated from different adrenal glands. 
A

\begin{tabular}{|c|c|c|}
\hline Steroid & Basal (\% total) & ACTH (\% total) \\
\hline \multicolumn{3}{|l|}{ 21-Carbon Steroids } \\
\hline Pregnenolone & $0.5 \pm 0.2$ & $0.2 \pm 0.1$ \\
\hline $17 \alpha$-Hydroxypregnenolone & $1 \cdot 0 \pm 0 \cdot 6$ & $0.7 \pm 0.4$ \\
\hline Progesterone & $0.6 \pm 0.2$ & $0 \cdot 1 \pm 0 \cdot 0$ \\
\hline $17 \alpha$-Hydroxyprogesterone & $4.9 \pm 1 \cdot 7$ & $2 \cdot 1 \pm 1 \cdot 1$ \\
\hline $20 \alpha$-Hydroxyprogesterone & ND & ND \\
\hline Deoxycorticosterone & $3.1 \pm 1.5$ & $1.0 \pm 0.5$ \\
\hline Corticosterone (B) & $13 \cdot 3 \pm 4 \cdot 0$ & $15 \cdot 7 \pm 4 \cdot 2$ \\
\hline Aldosterone & ND & ND \\
\hline 11-Deoxycortisol (S) & $8 \cdot 2 \pm 2 \cdot 3$ & $6 \cdot 2 \pm 1 \cdot 8$ \\
\hline Cortisol & $30 \cdot 5 \pm 6 \cdot 1$ & $59 \cdot 6 \pm 8 \cdot 3$ \\
\hline Cortisone (E) & $14 \cdot 7 \pm 3 \cdot 7$ & $1 \cdot 8 \pm 0.5$ \\
\hline 11-Dehydrocorticosterone (11-DHB) & $6 \cdot 1 \pm 2 \cdot 7$ & $0.9 \pm 0.4$ \\
\hline \multicolumn{3}{|l|}{ 19-Carbon steroids } \\
\hline DHEA & $0.4 \pm 0.1$ & $0 \cdot 3 \pm 0 \cdot 2$ \\
\hline DHEA-S & ND & $0.9 \pm 0.1$ \\
\hline $7 \alpha$-DHEA & ND & ND \\
\hline $16 \alpha-D H E A$ & ND & ND \\
\hline Androstenediol & ND & ND \\
\hline Androstenedione (A4) & $4 \cdot 1 \pm 2 \cdot 3$ & $3 \cdot 3 \pm 1 \cdot 8$ \\
\hline $11 \mathrm{OHA}$ & $8 \cdot 7 \pm 2 \cdot 3$ & $4 \cdot 8 \pm 1 \cdot 3$ \\
\hline Testosterone & ND & ND \\
\hline Dihydrotestosterone & ND & ND \\
\hline \multicolumn{3}{|l|}{ 18-Carbon steroids } \\
\hline Estrone & ND & ND \\
\hline Estradiol & ND & ND \\
\hline
\end{tabular}

B


Figure 4 Percentage of major steroids produced by AA cells with/without ACTH treatment. Primary human adrenal cells were isolated as described in Materials and Methods, and plated at a density of 300000 cells/well in 24-well dishes. Cells were treated with/without ACTH $(10 \mathrm{nM})$ in $0 \cdot 1 \%$ experimental medium for $48 \mathrm{~h}$ before harvest. The concentration of steroids in the medium was measured by LC-MS/MS and normalized to the amount of protein. Percentage of each steroid was calculated by dividing the amount of individual steroid with total steroid. (A) Table summarizing the percentage of individual steroid compared with total steroid produced by AA cells. (B) Pie chart summarizing the relative percentage of the major steroids produced in AA cells. Data represent results from three independent experiments and shown as means \pm s.E.M.; ND, not detectable.

controlling cortisol production, as has been reported for the enzyme aldosterone synthase in aldosterone biosynthesis. After ACTH treatment for $48 \mathrm{~h}$, cortisol production increased more than 60-fold, far exceeding that of its precursors, confirming the activating effect of ACTH on CYP11B1 (Xing et al. 2010). Analysis of steroid production pre- and poststimulation in the H295R cells also supports a role for CYP11B1 expression as a gate-keeper for cortisol biosynthesis. Both cortisol and 11OHA were significantly up-regulated by $48 \mathrm{~h}$ forskolin treatment and represented two of the major steroids produced by H295R cells after stimulation.

Human adrenocortical cells in vitro produce $\sim 1 / 5$ as much cortisone as cortisol in response to ACTH (Kolanowski \& Crabbe 1976). Higher levels of cortisone and 11-dehydrocorticosterone were reported in adrenal slices (Mazzocchi et al. 1998). Our data confirm that primary human adrenal cells can produce significant amounts of cortisone $(16 \%)$ and 11-dehydrocorticosterone (6\%) under basal condition. The mechanism and rationale for AA cortisone production are currently unclear. Based on past studies, there are at least two possibilities. First, there has been a report, using rat adrenal cells that demonstrated an increase in 11ß-hydroysteroid dehydrogenase (HSD11B) activity as a result of the cell isolation procedure (O'Hare \& Neville 1974). Second, several studies have shown that the human adrenal expresses HSD11B type 1 (HSD11B1) and type 2 (HSD11B2) transcripts and that both enzymatic activities can be seen using tissue lysates and tissue slices (Mazzocchi et al. 1998, 2002, Albertin et al. 2002).

While both DHEA and DHEA-S responded well to ACTH stimulation, the relative production of these steroids was lower than that might be expected from their reported abundance in systemic circulation. Several factors may 
A

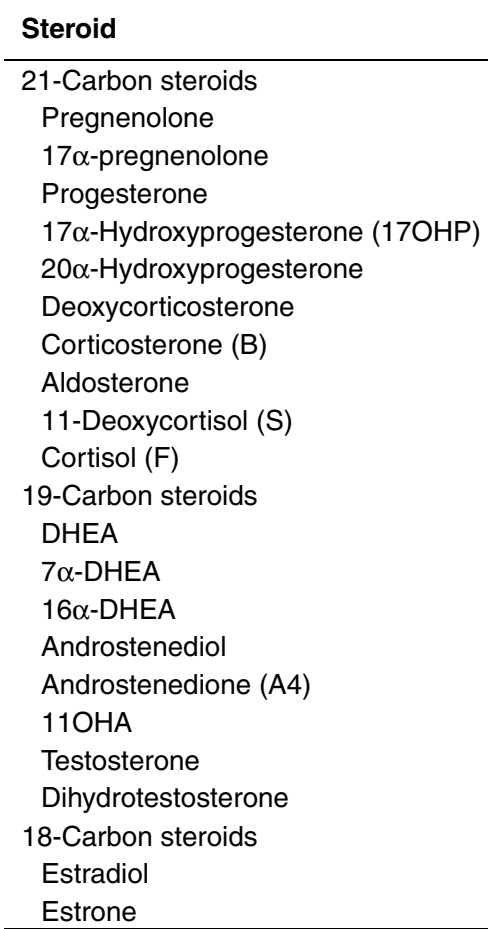

Basal (\% total) Forskolin (\% total)

\begin{tabular}{cc}
$0 \cdot 6 \pm 0 \cdot 2$ & $3 \cdot 7 \pm 0 \cdot 1$ \\
$1 \cdot 9 \pm 1 \cdot 0$ & $2 \cdot 0 \pm 1 \cdot 1$ \\
$0 \cdot 2 \pm 0 \cdot 1$ & $0 \cdot 1 \pm 0 \cdot 0$ \\
$6 \cdot 1 \pm 1 \cdot 6$ & $1 \cdot 6 \pm 0 \cdot 1$ \\
$\mathrm{ND}$ & $\mathrm{ND}$ \\
$2 \cdot 1 \pm 0 \cdot 2$ & $4 \cdot 1 \pm 1 \cdot 0$ \\
$3 \cdot 0 \pm 1 \cdot 3$ & $7 \cdot 9 \pm 1 \cdot 4$ \\
$\mathrm{ND}$ & $\mathrm{ND}$ \\
$42 \cdot 37 \pm 1 \cdot 1$ & $29 \cdot 8 \pm 2 \cdot 9$ \\
$9 \cdot 6 \pm 3 \cdot 4$ & $25 \cdot 7 \pm 5 \cdot 6$ \\
& \\
$1 \cdot 3 \pm 0.8$ & $1 \cdot 2 \pm 0 \cdot 7$ \\
$\mathrm{ND}$ & $\mathrm{ND}$ \\
$\mathrm{ND}$ & $\mathrm{ND}$ \\
$\mathrm{ND}$ & $\mathrm{ND}$ \\
$28 \cdot 6 \pm 4 \cdot 5$ & $21 \cdot 0 \pm 2 \cdot 8$ \\
$3 \cdot 0 \pm 1 \cdot 1$ & $3 \cdot 5 \pm 0 \cdot 1$ \\
$0.5 \pm 0 \cdot 1$ & $0 \cdot 3 \pm 0 \cdot 0$ \\
$\mathrm{ND}$ & $\mathrm{ND}$ \\
& \\
$0.01 \pm 0 \cdot 0$ & $0 \cdot 07 \pm 0 \cdot 0$ \\
$0.3 \pm 0.1$ & $0 \cdot 2 \pm 0 \cdot 03$ \\
\hline
\end{tabular}

B



Forskolin steroids

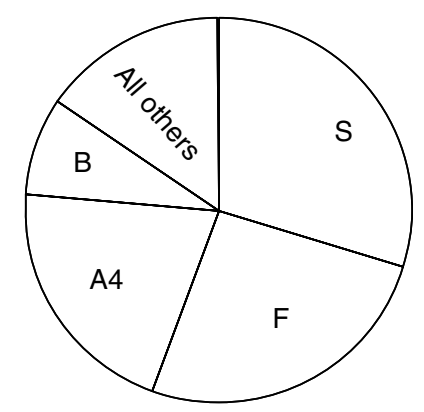

Figure 5 Percentage of major steroids produced by H295R cells with/without forskolin treatment. Three independent strains of the H295R adrenal cell model were cultured as described in Materials and Methods, and plated at a density of 400000 cells/well in 12 -well dishes. Cells were treated with/without forskolin $(10 \mu \mathrm{M})$ in $0 \cdot 1 \%$ experimental medium for $48 \mathrm{~h}$ before harvest. The concentration of steroids in the medium was measured by LC-MS/MS. Percentage of each steroid was calculated by dividing the amount of individual steroid with total steroid. (A) Table summarizing the percentage of individual steroid compared to total steroid produced by H295R cells. (B) Pie chart summarizing the relative percentage of four major steroids produced in H295R cells. Data represent results from three independent experiments and shown as means \pm s.E.M.; ND, not detectable.

influence the production of $\Delta 5 \mathrm{C} 19$ steroids by primary adrenal cell cultures, including alterations that occurred in vivo prior to cell isolation and the relative proportion of $\mathrm{ZF}$ and $\mathrm{ZR}$ cells in the culture. According to the clinical data supplied for two of the adrenal donors, the adrenal glands came from young patients (age range 21-22 years old) who had sustained severe automobile accident injuries and died of intracranial hemorrhage/stroke. Adrenal glands were collected 2-3 days after brain death. Studies from several independent groups have reported decreased DHEA and DHEA-S levels in severely ill patients, while androstenedione and cortisol concentrations remained stable (Parker et al. 1985, Luppa et al. 1991, Beishuizen et al. 2002). Our data from primary cultures coincide with previous findings by showing decreased levels of DHEA in both basal and ACTH-treated groups. Regarding cell types, ZR cells mainly release DHEA (Endoh et al. 1996), which during our incubation period may be transformed by the mixed fasciculata/reticularis cultures to $\Delta 4$ steroids (androstenedione and $11 \mathrm{OHA}$ ), decreasing the apparent production of DHEA.

Interestingly, androstenedione and $11 \mathrm{OHA}$ were produced in large amounts even in unstimulated AA cells. Compared with the data of Fearon et al. (1998), our cells have a lower cortisol/androstenedione ratio ( 6 vs 20 ). The difference may relate to their use of freshly isolated cells or their treatment time of only $2 \mathrm{~h}$. Alternatively, AA cells in monolayer culture may produce more androstenedione under chronic ACTH treatment.

Androstenedione is more readily converted to testosterone than DHEA or DHEA-S (Zipser et al. 1981). Testosterone functions as a more active androgen than androstenedione in circulation. Several studies have shown that the adrenal gland contributes to testosterone production by either direct secretion or peripheral conversion of adrenal-derived precursor (Keymolen et al. 1976, Macdonald \& Matt 1984, Fenske 1986, Canonaco et al. 1989, Nakamura et al. 2009). In addition, the contribution of adrenal gland to circulating testosterone in women is particularly important. However, in the present study, we were not able to detect testosterone in the medium. However, this may relate to our relatively low limit for detection of $50 \mathrm{ng} / \mathrm{ml}$ or the relative number of reticularis cells in the mixed culture. The lack of detection in the primary cultures contrasts with our findings in the H295R adrenocortical cell line, which show detectable 
levels of testosterone even under unstimulated conditions (Nakamura et al. 2009). Our data support the concept that the H295R adrenal carcinoma cell models produce more testosterone and estrone than the primary adrenal cell cultures. This is probably due to the high expression of $17 \beta$-hydroxysteroid dehydrogenase type 5 (HSD17B5) and significant expression of aromatase (CYP19) in the H295R cells compared with normal adrenal cells (Staels et al. 1993, Nakamura et al. 2009). It should also be noted that our primary cultures of adrenal cells produced only low levels of DHEA, suggesting that the mixed cortical cells may exhibit more of a fasciculata phenotype, while H295R produces a variety of adrenal steroids, including mineralocorticoids, glucocorticoids, estrogens, and androgens. Further experiments will be needed to differentiate the role of $\mathrm{ZF}$ and $\mathrm{ZR}$ in testosterone production in human adrenal glands.

In summary, using LC-MS/MS for steroid analysis, we characterized the relative production of a wide range of steroids in primary cultures of normal adrenal cells and the H295R adrenal cell lines. This represents the first comprehensive study using LC-MS/MS to examine the production of steroids by adrenal cells in culture. The current report should serve as a reference for researchers studying adrenal steroidogenesis using either normal cells in culture or the H295R adrenal cell line.

\section{Supplementary data}

This is linked to the online version of the paper at http://dx.doi.org/10.1530/ JOE-10-0493.

\section{Declaration of interest}

The authors declare that there is no conflict of interest that could be perceived as prejudicing the impartiality of the research reported.

\section{Funding}

This work was supported by National Institute of Health grants DK069950 (W E R), DK43140 (W E R), MCG Cardiovascular Discovery Institute Synergy Award (W E R and M A E), and a Diabetes and Obesity Discovery Institute Pilot Grant (M A E).

\section{Acknowledgements}

We thank Georgia Health University Adrenal Center for helping to collect adrenal samples and Dr Mary Bassett who provided professional editorial assistance in the writing of the manuscript.

\section{References}

Albertin G, Tortorella C, Malendowicz LK, Aragona F, Neri G \& Nussdorfer GG 2002 Human adrenal cortex and aldosterone secreting adenomas express both 11beta-hydroxysteroid dehydrogenase type 1 and type 2 genes. International Journal of Molecular Medicine 9 495-498.
Arvat E, Di Vito L, Lanfranco F, Maccario M, Baffoni C, Rossetto R, Aimaretti G, Camanni F \& Ghigo E 2000 Stimulatory effect of adrenocorticotropin on cortisol, aldosterone, and dehydroepiandrosterone secretion in normal humans: dose-response study. Journal of Clinical Endocrinology and Metabolism 85 3141-3146. (doi:10.1210/jc.85.9.3141)

Bassett MH, Suzuki T, Sasano H, De Vries CJ, Jimenez PT, Carr BR \& Rainey WE 2004 The orphan nuclear receptor NGFIB regulates transcription of 3beta-hydroxysteroid dehydrogenase. Implications for the control of adrenal functional zonation. Journal of Biological Chemistry 279 37622-37630. (doi:10.1074/jbc.M405431200)

Beishuizen A, Thijs LG \& Vermes I 2002 Decreased levels of dehydroepiandrosterone sulphate in severe critical illness: a sign of exhausted adrenal reserve? Critical Care 6 434-438. (doi:10.1186/cc1530)

Branchaud CL, Goodyer CG \& Lipowski LS 1983 Progesterone and estrogen production by placental monolayer cultures: effect of dehydroepiandrosterone and luteinizing hormone-releasing hormone. Journal of Clinical Endocrinology and Metabolism 56 761-766. (doi:10.1210/jcem-56-4-761)

Burger HG 2002 Androgen production in women. Fertility and Sterility 77 (Supplement 4) S3-S5. (doi:10.1016/S0015-0282(02)02985-0)

Canonaco M, Ando S, Valenti A, Tavolaro R, Panno ML, Maggiolini M \& Dessi-Fulgheri F 1989 The in-vitro transformation of [3H]dehydroepiandrosterone into its principal metabolites in the adrenal cortex of adult castrated male rats and following steroid treatment. Journal of Endocrinology 121 419-424. (doi:10.1677/joe.0.1210419)

Chen C, Belanger A \& Labrie F 1996 Adrenal steroid precursors exert potent androgenic action in the hamster sebaceous glands of flank organs and ears. Endocrinology 137 1752-1757. (doi:10.1210/en.137.5.1752)

Di Blasio AM, Fujii DK, Yamamoto M, Martin MC \& Jaffe RB 1990 Maintenance of cell proliferation and steroidogenesis in cultured human fetal adrenal cells chronically exposed to adrenocorticotropic hormone: rationalization of in vitro and in vivo findings. Biology of Reproduction $\mathbf{4 2}$ 683-691. (doi:10.1095/biolreprod42.4.683)

Endoh A, Kristiansen SB, Casson PR, Buster JE \& Hornsby PJ 1996 The zona reticularis is the site of biosynthesis of dehydroepiandrosterone and dehydroepiandrosterone sulfate in the adult human adrenal cortex resulting from its low expression of 3 beta-hydroxysteroid dehydrogenase. Journal of Clinical Endocrinology and Metabolism 81 3558-3565. (doi:10.1210/ jc.81.10.3558)

Fearon U, Clarke D, McKenna TJ \& Cunningham SK 1998 Intra-adrenal factors are not involved in the differential control of cortisol and adrenal androgens in human adrenals. European Journal of Endocrinology 138 567-573. (doi:10.1530/eje.0.1380567)

Fenske M 1986 Basal and HCG-stimulated testosterone production by interstitial cells of the Mongolian gerbil (Meriones unguiculatus) - II. Influence of glucocorticosteroids and steroidal precursors. Comparative Biochemistry and Physiology. A, Comparative Physiology 85 273-279. (doi:10.1016/0300-9629(86)90250-1)

Fottner C, Engelhardt D \& Weber MM 1998 Regulation of steroidogenesis by insulin-like growth factors (IGFs) in adult human adrenocortical cells: IGF-I and, more potently, IGF-II preferentially enhance androgen biosynthesis through interaction with the IGF-I receptor and IGF-binding proteins. Journal of Endocrinology 158 409-417. (doi:10.1677/joe.0. 1580409)

Grant JK 1962 Studies on the biogenesis of the adrenal steroids. British Medical Bulletin 18 99-105.

Guillon G, Trueba M, Joubert D, Grazzini E, Chouinard L, Cote M, Payet MD, Manzoni O, Barberis C, Robert M et al. 1995 Vasopressin stimulates steroid secretion in human adrenal glands: comparison with angiotensin-II effect. Endocrinology 136 1285-1295. (doi:10.1210/en.136. 3.1285)

Haning RV Jr, Austin CW, Carlson IH, Kuzma DL \& Zweibel WJ 1985 Role of dehydroepiandrosterone sulfate as a prehormone for ovarian steroidogenesis. Obstetrics and Gynecology 65 199-205.

Hornsby PJ \& Gill GN 1977 Hormonal control of adrenocortical cell proliferation. Desensitization to ACTH and interaction between ACTH and fibroblast growth factor in bovine adrenocortical cell cultures. Journal of Clinical Investigation 60 342-352. (doi:10.1172/JCI108782) 
Hornsby PJ, O'Hare MJ \& Neville AM 1973 Effect of ACTH on biosynthesis of aldosterone and corticosterone by monolayer cultures of rat adrenal zona glomerulosa cells. Biochemical and Biophysical Research Communications 54 1554-1559. (doi:10.1016/0006-291X(73)91163-7)

Hung TT \& LeMaire WJ 1988 The effects of corticotropin, opioid peptides and crude pituitary extract on the production of dehydroepiandrosterone and corticosterone by mature rat adrenal cells in tissue culture. Journal of Steroid Biochemistry 29 721-726. (doi:10.1016/0022-4731(88)90174-4)

Israeli E, Levy J, Rosental E, Auslaender L, Peleg I \& Barzilai D 1975 A human adrenocortical adenoma in tissue culture. Morphology and hormone secretion. Israel Journal of Medical Sciences 11 1106-1113.

Keymolen V, Dor P \& Borkowski A 1976 Output of oestrogens, testosterone and their precursors by isolated human adrenal cells as compared with that of glucocorticosteroids. Journal of Endocrinology 71 219-229. (doi:10.1677/ joe.0.0710219)

Kolanowski J \& Crabbe J 1976 Characteristics of the response of human adrenocortical cells to ACTH. Molecular and Cellular Endocrinology $\mathbf{5}$ 255-267. (doi:10.1016/0303-7207(76)90088-5)

Labrie F, Belanger A, Luu-The V, Labrie C, Simard J, Cusan L, Gomez JL \& Candas B 1998 DHEA and the intracrine formation of androgens and estrogens in peripheral target tissues: its role during aging. Steroids $\mathbf{6 3}$ 322-328. (doi:10.1016/S0039-128X(98)00007-5)

Lebrethon MC, Jaillard C, Naville D, Begeot M \& Saez JM 1994a Regulation of corticotropin and steroidogenic enzyme mRNAs in human fetal adrenal cells by corticotropin, angiotensin-II and transforming growth factor beta 1. Molecular and Cellular Endocrinology 106 137-143. (doi:10.1016/ 0303-7207(94)90195-3)

Lebrethon MC, Jaillard C, Naville D, Begeot M \& Saez JM $1994 b$ Effects of transforming growth factor-beta 1 on human adrenocortical fasciculatareticularis cell differentiated functions. Journal of Clinical Endocrinology and Metabolism 79 1033-1039. (doi:10.1210/jc.79.4.1033)

Luppa P, Munker R, Nagel D, Weber M \& Engelhardt D 1991 Serum androgens in intensive-care patients: correlations with clinical findings. Clinical Endocrinology 34 305-310. (doi:10.1111/j.1365-2265.1991. tb03771.x)

Macdonald GJ \& Matt DW 1984 Adrenal and placental steroid secretion during pregnancy in the rat. Endocrinology 114 2068-2073. (doi:10.1210/ endo-114-6-2068)

Mahaffee D, Reitz RC \& Ney RL 1974 The mechanism of action of adrenocroticotropic hormone. The role of mitochondrial cholesterol accumulation in the regulation of steroidogenesis. Journal of Biological Chemistry 249 227-233.

Mason PA \& Fraser R 1975 Estimation of aldosterone, 11-deoxycorticosterone, 18-hydroxy-11-deoxy-corticosterone, corticosterone, cortisol and 11-deoxycortisol in human plasma by gas-liquid chromatography with electron capture detection. Journal of Endocrinology 64 277-288. (doi:10.1677/joe.0.0640277)

Mazzocchi G, Rossi GP, Neri G, Malendowicz LK, Albertin G \& Nussdorfer GG 1998 11Beta-hydroxysteroid dehydrogenase expression and activity in the human adrenal cortex. FASEB Journal 12 1533-1539.

Mazzocchi G, Malendowicz LK, Aragona F, Tortorella C, Gottardo L \& Nussdorfer GG 2002 11Beta-hydroxysteroid dehydrogenase types 1 and
2 are up- and downregulated in cortisol-secreting adrenal adenomas. Journal of Investigative Medicine 50 288-292. (doi:10.2310/6650.2002. 33012)

Morgan MW \& O'Hare MJ 1979 Cytotoxic drugs and the human adrenal cortex: a cell culture study. Cancer 43 969-979. (doi:10.1002/10970142(197903)43:3<969::AID-CNCR2820430328>3.0.CO;2-5)

Nakamura Y, Hornsby PJ, Casson P, Morimoto R, Satoh F, Xing Y, Kennedy MR, Sasano H \& Rainey WE 2009 Type 5 17betahydroxysteroid dehydrogenase (AKR1C3) contributes to testosterone production in the adrenal reticularis. Journal of Clinical Endocrinology and Metabolism 94 2192-2198. (doi:10.1210/jc.2008-2374)

Ney RL, Hochella NJ, Grahame-Smith DG, Dexter RN \& Butcher RW 1969 Abnormal regulation of adenosine $3^{\prime}, 5^{\prime}$-monophosphate and corticosterone formation in an adrenocortical carcinoma. Journal of Clinical Investigation 48 1733-1739. (doi:10.1172/JCI106139)

O'Hare MJ \& Neville AM 1974 The trophic responses of cultured adrenocortical cells to ACTH. Proceedings of the Royal Society of Medicine 67747.

O’Hare MJ, Nice EC, Magee-Brown R \& Bullman H 1976 High-pressure liquid chromatography of steroids secreted by human adrenal and testis cells in monolayer culture. Journal of Chromatography 125 357-367. (doi:10.1016/S0021-9673(00)93831-7)

Parker LN, Levin ER \& Lifrak ET 1985 Evidence for adrenocortical adaptation to severe illness. Journal of Clinical Endocrinology and Metabolism 60 947-952. (doi:10.1210/jcem-60-5-947)

Sharma RK 1973 Regulation of steroidogenesis by adrenocorticotropic hormone in isolated adrenal cells of rats. Journal of Biological Chemistry $\mathbf{2 4 8}$ 5473-5476.

Sirianni R, Mayhew BA, Carr BR, Parker CR Jr \& Rainey WE 2005 Corticotropin-releasing hormone (CRH) and urocortin act through type 1 $\mathrm{CRH}$ receptors to stimulate dehydroepiandrosterone sulfate production in human fetal adrenal cells. Journal of Clinical Endocrinology and Metabolism 90 5393-5400. (doi:10.1210/jc.2005-0680)

Staels B, Hum DW \& Miller WL 1993 Regulation of steroidogenesis in NCI-H295 cells: a cellular model of the human fetal adrenal. Molecular Endocrinology 7 423-433. (doi:10.1210/me.7.3.423)

Watanabe M \& Nakajin S 2004 Forskolin up-regulates aromatase (CYP19) activity and gene transcripts in the human adrenocortical carcinoma cell line H295R. Journal of Endocrinology 180 125-133. (doi:10.1677/joe.0. 1800125)

Xing Y, Parker CR, Edwards M \& Rainey WE 2010 ACTH is a potent regulator of gene expression in human adrenal cells. Journal of Molecular Endocrinology 45 59-68. (doi:10.1677/JME-10-0006)

Zipser RD, Davenport MW, Martin KL, Tuck ML, Warner NE, Swinney RR, Davis CL \& Horton R 1981 Hyperreninemic hypoaldosteronism in the critically ill: a new entity. Journal of Clinical Endocrinology and Metabolism $\mathbf{5 3}$ 867-873. (doi:10.1210/jcem-53-4-867)

Received in final form 24 February 2011
Accepted 18 March 2011

Made available online as an Accepted Preprint 23 March 2011 